\title{
Physiological reactions of men using microclimate cooling in hot humid environments
}

\author{
A. J. VAN RENSBURG, D. MITCHELL, W. H. VAN DER WALT, \\ and N. B. STRYDOM \\ Human Sciences Laboratory, Chamber of Mines of South Africa, Johannesburg, \\ South Africa
}

\begin{abstract}
van Rensburg, A. J., Mitchell, D., van der Walt, W. H., and Strydom, N. B. (1972). Brit. J. industr. Med., 29, 387-393. Physiological reactions of men using microclimate cooling in hot humid environments. This paper describes the laboratory testing of a water-cooled vest and of a pre-frozen jacket on men working in hot humid environments. The work rate used in the tests was comparable with that of moderately hard industrial work. Three measures of strain were used, namely, rectal temperature, heart rate, and sweat rate. The tests showed that the water-cooled vest provided protection physiologically equivalent to removing the entire environmental heat stress, even at wet bulb temperatures of $33.9^{\circ} \mathrm{C}$. The pre-frozen jackets provided better protection at $32.2^{\circ} \mathrm{C}$ wet bulb than at $33.9^{\circ} \mathrm{C}$ wet bulb. The garments have the potential to restore the loss in productivity caused by heat stress.
\end{abstract}

Microclimate conditioning has been introduced in industrial and military operations throughout the world as a means for protecting men against heat. However, very few systematic physiological studies have been conducted to assess the performance of microclimate conditioning in terms of the reactions of men using microclimate cooling. The study reported here deals with the physiological reactions of men wearing either a liquid-conditioned garment or a phase-change garment during extended work in hot humid environments. The garments were tested under conditions comparable to the most stressful conditions found or expected in the South African gold mines.

The liquid-conditioned garment was a watercooled vest of the type originally developed at the Royal Aircraft Establishment (Burton, 1964) and recently reviewed by Nunneley (1970). The phasechange garment used the latent heat of ice to extract heat from the wearer's body. The garment was similar to the one described by Blockey (1970) though considerably more simple in construction.

\section{Methods}

Subjects

Two healthy young Bantu men acted as subjects. Their physical characteristics are given in Table 1. Their body

T A B L E 1

Physical Characteristics of Subjects

\begin{tabular}{l|c|c|c|c}
\hline Subject & $\begin{array}{c}\text { Age } \\
(y r)\end{array}$ & $\begin{array}{c}\text { Height } \\
(\mathrm{cm})\end{array}$ & $\begin{array}{c}\text { Weight } \\
(\mathrm{kg})\end{array}$ & $\begin{array}{c}\text { Maximum } \\
\text { aerobic } \\
\text { capacity } \\
\text { (litres/min })\end{array}$ \\
\hline DUS & 20 & $173 \cdot 2$ & $63 \cdot 3 \pm 0 \cdot 9$ & $2 \cdot 8$ \\
ORL & 20 & $163 \cdot 4$ & $61 \cdot 1 \pm 0 \cdot 7$ & $2 \cdot 9$ \\
\hline
\end{tabular}


weights are given as the mean (and standard deviation) over the entire period of the study.

Both men were acclimatized to work in humid heat, using a standard acclimatization procedure developed at the Human Sciences Laboratory (Wyndham et al., 1964).

\section{Description of cooling systems}

The two types of jacket used in the investigation will be referred to as the 'water-cooled vest' and the 'pre-frozen jacket'. Both vest and jacket covered the torso of the subject, leaving the arms, legs, head, and neck bare.

Water-cooled vest The water-cooled vest was a type available commercially ${ }^{1}$. It was a sleeveless waistcoat made of an elastic fabric to the inside of which a network of small-diameter plastic tubing was attached. The tubes were in direct contact with the skin. The total length of the tubing was about $47 \mathrm{~m}$. The small tubes were connected in parallel to one common inlet and one common outlet. A thermocouple was installed with one junction in the inlet and the other in the outlet so that the rise in temperature of the water perfusing the vest could be measured.

The water-cooled vest was designed by its manufacturers to be worn under other clothing. In order to insulate the cooling tubes from the hot humid environment a layer of open-cell foam plastic, about $12.5 \mathrm{~mm}$ thick, was stitched to the outside of the vest. Over the insulation the subject wore a skin-diver's wet suit. The rubber wet suit provided a barrier to atmospheric water vapour and also pressed the tubing network tightly against the subject's body.

The water-cooled vest was supplied with cold water from the laboratory's permanently chilled water supply. The cooling water was pumped through the jacket at a rate of about 48 to 54 litres per hour.

Pre-frozen jacket Two pre-frozen jackets were used, both of which were constructed in the laboratory. The garment consisted of a sleeveless canvas jacket on the outside of which sealed plastic bags containing a freezable liquid were attached. Only one thickness of canvas separated the frozen bags from the subject's skin. In one jacket the bags were made of ordinary PVC filled with about $250 \mathrm{~g}$ of tap water. The other jacket was fitted with commercially available bags $^{2}$ of the type used by campers and picnickers to keep food cold. They contained a proprietary jelly-like substance. In both instances the total weight of the bags was about $4.5 \mathrm{~kg}$. During melting, the ice absorbed about $1500 \mathrm{~kJ}$ of heat. Heating of the water so formed toward skin temperature absorbed a maximum of a further $660 \mathrm{~kJ}$. Although the thermal capacity of the proprietary jelly was not known no difference was observed in the cooling powers of the two types of bag which will, therefore, not be distinguished in further discussion.

An insulating layer of about $\mathbf{1 2 . 5} \mathrm{mm}$ of foam plastic was stitched to the outside of the bags and a canvas jacket of a larger size was attached to the outside of the

${ }^{1}$ B. Welson \& Co., Inc., 104 Ledyard Street, Hartford, Connecticut 06114, United States of America

2Alaska, Pakamac South Africa (Pty.) Ltd. foam. The pre-frozen jackets were fastened by lacing them up the front.

When the jackets were donned the ice was at a temperature just below freezing point. The thermal state of the jackets at the end of exposures was not measured.

\section{Experimental procedure}

The experiments were designed to compare the three measures of physiological strain-rectal temperature, heart rate, and sweat rate, in men working nude in a neutral environment, nude in a hot, humid environment, and in the same hot, humid environment but protected by a cooling system.

The men worked at a rate of 35 watts in all the experiments by stepping on and off an adjustable block 12 times per minute. The height of the block was set according to the subject's daily weight, including that of the jacket or vest where applicable, to achieve the correct work rate. This task has been shown (Wyndham et al., 1964) to have an oxygen demand of 0.93 litres/min in Bantu, or a metabolic energy consumption of about 300 watts.

On the first day of a cycle, the subject exercised nude in a neutral environment, on the second day nude in the test environment, and, on the third day, protected by jacket or vest in the test environment. The cycle was repeated until each subject had been exposed twice in the water-cooled vest and twice in the pre-frozen jackets to each test environment. Each stage of the experiment therefore generally consisted of four nude exposures to the neutral environment, four nude exposures to the test environment, and two exposures to the test environment in each jacket or vest.

Rectal temperatures, heart rates, and sweat rates were measured regularly during every exposure (Fig. 1) using standard techniques (Wyndham et al., 1964).

Throughout the experiment each man drank $250 \mathrm{~g}$ of water every half hour in order to maintain as constant a state of hydration as possible. The men worked for either four or six hours daily. During the six-hour studies all physiological measurements were made at hourly intervals instead of half-hourly intervals.

No attempt was made to measure the amount of heat taken up by the pre-frozen jackets. The heat removed by the water-cooled vest was calculated by measuring the flow rate and the difference between the temperatures of the water entering and leaving the vest.

\section{Statistical analysis of results}

A method proposed by Dunn (1961) was used to analyse the measurements of rectal temperature, heart rate, and sweat rate. The method permits confidence limits to be attached to one of a series of mean values, the limits taking into account the variance not only in that mean value but throughout the series. The other mean value differs from the first if they lie outside the confidence interval so formed. Using Dunn's method, 95\% significance intervals were attached to the mean of the two test values. The significance interval was calculated using all the test and control values for that particular period.

When the mean of the neutral control values fell within the $95 \%$ interval around the test values, the test values were not significantly different from the neutral control values. Similarly, when the mean of the hot 


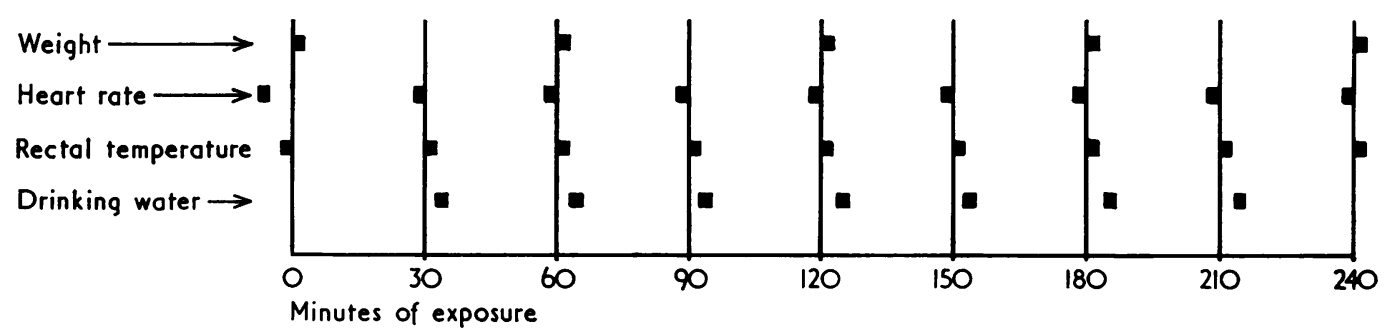

FIG. 1. General experimental design.

control values lay within this interval, the test values were not significantly different from the hot control values.

Dunn's approach assumes that for a particular variable at a particular time the test values and the control values are normally distributed about their means and have the same variance. This assumption was not strictly valid in the present investigation, but it is believed that the errors introduced in the tests of significance were small.

\section{Results}

\section{Acclimatization}

Subject DUS showed the typical acclimatization response (Wyndham et al., 1964) but subject ORL showed hardly any signs of acclimatization. The reactions of the two subjects were therefore analysed separately.

Reactions during 4 hours of work at $32 \cdot 2^{\circ} \mathrm{C}$ wet bulb The reactions of the men wearing the two microclimate conditioners were assessed in an environment of $33.9^{\circ} \mathrm{C}$ dry bulb and $32.2^{\circ} \mathrm{C}$ wet bulb at low wind velocity (less than $0.5 \mathrm{~m} / \mathrm{sec}$ ).

During this part of the experiment the watercooled vest was perfused with water at a temperature of about $12^{\circ} \mathrm{C}$. Both the pre-frozen jackets were used. The first was donned at the beginning of the exposure and the second after two hours.

Water-cooled vest The temperature used during the tests of the water-cooled vest are given in Table 2. The physiological strain measurements and the rate of removal of heat by water for the two subjects are shown in Figure 2.

Subject DUS's heart rate and sweat rate were significantly lower when he wore the water-cooled vest than when he was unprotected, except during the first hour of exposure. His rectal temperature was on the verge of being significantly lower. Subject ORL's rectal temperature, heart rate, and sweat rate were all significantly depressed, again except during the first hour.

More important was the fact that, except for some of ORL's heart rates, there was no difference 2
T A B L E 2

ENVIRONMENTAL TEMPERATURES

\begin{tabular}{|c|c|c|c|}
\hline & $\begin{array}{c}\text { Dry bulb } \\
{ }^{\circ} \mathrm{C}\end{array}$ & $\begin{array}{c}\text { Wet bulb } \\
{ }^{\circ} \mathrm{C}\end{array}$ & $\begin{array}{c}\text { Water } \\
\text { temperature } \\
{ }^{\circ} \mathrm{C}\end{array}$ \\
\hline $\begin{array}{l}\text { Test of vest } \\
\text { Neutral control } \\
\text { Hot control } \\
\text { Test }\end{array}$ & $\begin{array}{l}24 \cdot 2 \pm 0 \cdot 6 \\
34 \cdot 0 \pm 0 \cdot 1 \\
33 \cdot 9 \pm 0 \cdot 1\end{array}$ & $\begin{array}{l}18 \cdot 2 \pm 0 \cdot 4 \\
32 \cdot 3 \pm 0 \cdot 1 \\
32 \cdot 3 \pm 0 \cdot 1\end{array}$ & $\frac{\bar{Z}}{11 \cdot \overline{6 \pm 0.6}}$ \\
\hline $\begin{array}{l}\text { Test of jacket } \\
\text { Neutral control } \\
\text { Hot control } \\
\text { Test }\end{array}$ & $\begin{array}{l}22 \cdot 6 \pm 3 \cdot 3 \\
33 \cdot 9 \pm 0 \cdot 1 \\
34 \cdot 0 \pm 0 \cdot 1\end{array}$ & $\begin{array}{l}16 \cdot 3 \pm 2 \cdot 8 \\
32 \cdot 3 \pm 0 \cdot 1 \\
32 \cdot 3 \pm 0 \cdot 1\end{array}$ & E \\
\hline $\begin{array}{l}\text { High wet-bulb } \\
\text { test } \\
\text { Neutral control } \\
\text { Hot control } \\
\text { Test }\end{array}$ & $\begin{array}{l}20 \cdot 0 \pm 0 \cdot 5 \\
35 \cdot 6 \pm 0 \cdot 1 \\
35 \cdot 6 \pm 0 \cdot 1\end{array}$ & $\begin{array}{l}16.4 \pm 0.2 \\
33.8 \pm 0 \cdot 1 \\
33.9 \pm 0.1\end{array}$ & $\overline{\bar{z}}$ \\
\hline
\end{tabular}

between the men's reactions when they were wearing the water-cooled vest in an environment of $33.9^{\circ} \mathrm{C}$ dry bulb and $32.2^{\circ} \mathrm{C}$ wet bulb and their reactions when they were doing the same work in a neutral environment. The protection given by the vest was physiologically equivalent to removing the environmental heat stress entirely. Wearing the vest generally reduced rectal temperatures to below $37.5^{\circ} \mathrm{C}$, heart rate to below 100 beats $/ \mathrm{min}$, and sweat rate to $40 \%$ of its control value.

The rate at which the water removed heat was about 200 watts for each subject, which should be compared with the metabolic generation of 300 watts. Not all the heat picked up by the water originated from the subject. Some certainly originated from the environment, particularly from the condensation of water vapour. The vest did not remove all the metabolic heat, but sufficient of it to eliminate the thermally-induced strain.

Pre-frozen jacket The conditions prevailing during the test of the pre-frozen jacket are summarized in 

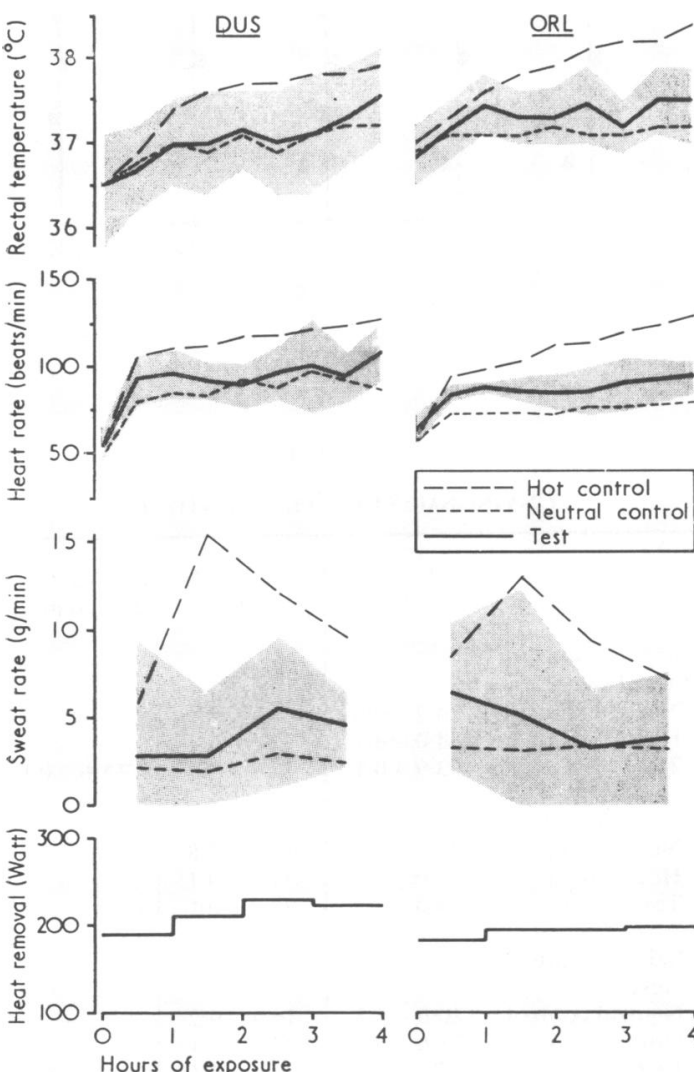

FIG. 2. Reactions of men wearing water-cooled vests supplied with 50 litres/hr of water at $12^{\circ} \mathrm{C}$. Dry bulb temperature $33.9^{\circ} \mathrm{C}$, wet bulb temperature $32 \cdot 2^{\circ} \mathrm{C}$.

Table 2. The physiological reactions of the two subjects are displayed in Figure 3.

The pre-frozen jacket did not provide as much protection as did the water-cooled vest. The protection provided, however, was still considerable. The rectal temperatures of both subjects were depressed significantly below the hot control values for the last two and a half hours of exposure, and maintained at $37.5^{\circ} \mathrm{C}$ or below. Except for the last hour there was no difference between the rectal temperatures when the men were wearing the jackets and when they were doing the same work in the neutral environment.

Heart rate during the jacket test tended to be lower than the hot control values but higher than the neutral control values. Heart rates were maintained at below 105 beats/min by the pre-frozen jackets.

Sweat rates were again depressed considerably to about $50 \%$ of the control values. The test rates did not differ significantly from the sweat rates in the neutral environments but also did not always differ

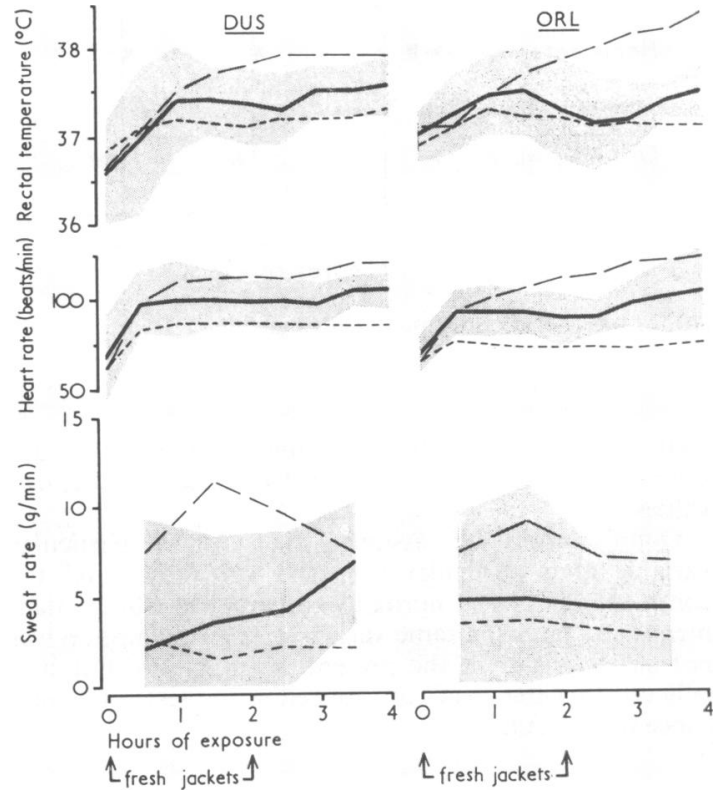

FIG. 3. Reactions of men wearing pre-frozen jackets donned at 0 and 2 hours. Dry bulb temperature $34.0^{\circ} \mathrm{C}$, wet bulb temperature $32 \cdot 3^{\circ} \mathrm{C}$.

significantly from the control sweat rates under hot conditions.

Reactions during 4 hours of work at $33.9^{\circ} \mathrm{C}$ wet bulb Both cooling systems were also tested in an environment at $33.9^{\circ} \mathrm{C}$ wet bulb temperature. The exact temperatures are given in Table 2 . The results for the water-cooled vest are displayed in Fig. 4 and those for the pre-frozen jackets in Figure 5.

Under the environmental conditions of this test, neither subject, when unprotected, was able to reach equilibrium with his environment. Both had rectal temperatures rising steadily throughout exposure in the nude. The rectal temperature of the heatintolerant subject, ORL, had nearly reached the $40^{\circ} \mathrm{C}$ limit of safety after four hours. The subjects had heart rates in the region of 160 beats/min.

If the reactions of the subjects when they were wearing water-cooled vests at a wet bulb temperature of $33.9^{\circ} \mathrm{C}$ are compared with their reactions in the vests at $32.2^{\circ} \mathrm{C}$ wet bulb (Figs 2 and 4 ) it is clear that there is very little decrease in the effectiveness of the vest. Except for ORL's heart rate, the reactions of the men when exposed to temperatures of $35.6^{\circ} \mathrm{C}$ dry bulb and $33.9^{\circ} \mathrm{C}$ wet bulb while wearing the vest were statistically indistinguishable from their reactions when they were doing the same work in the nude in a neutral environment. The vest once 


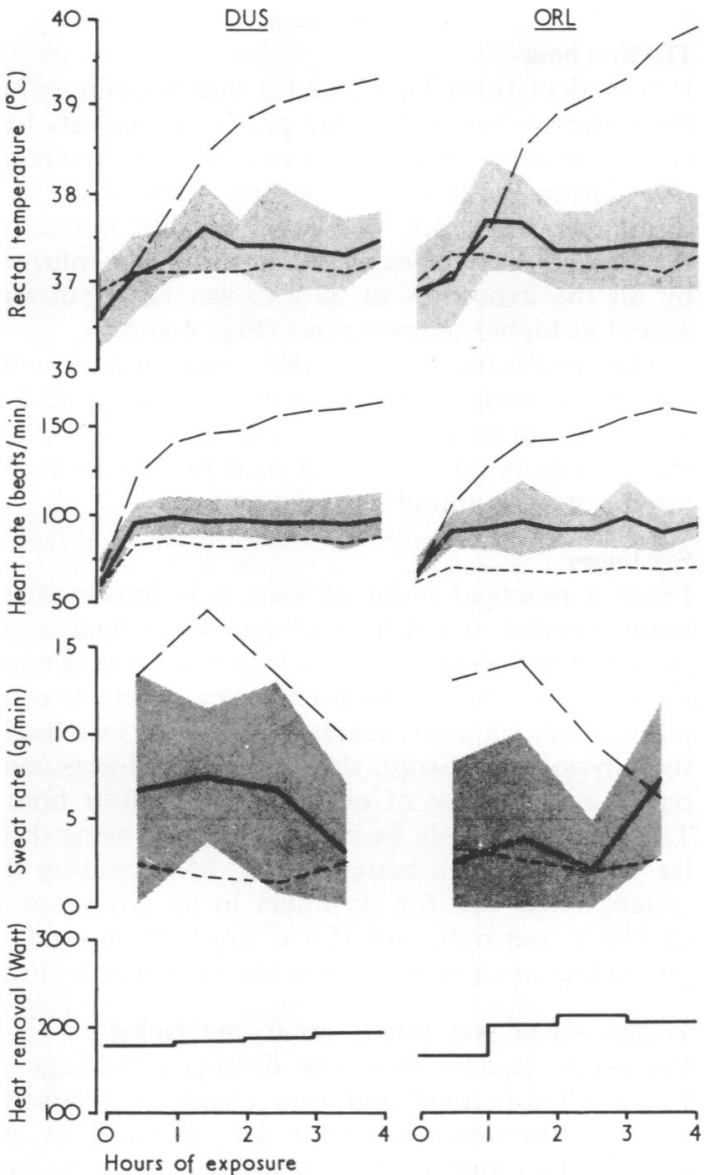

FIG. 4. Reactions of men wearing water-cooled vests supplied with 50 litres $/ \mathrm{hr}$ of water at $10^{\circ} \mathrm{C}$. Dry bulb temperature $35.6^{\circ} \mathrm{C}$, wet bulb temperature $33.9^{\circ} \mathrm{C}$.

again counteracted the environmental heat stress completely.

The pre-frozen jackets were not as effective at $33.9^{\circ} \mathrm{C}$ wet bulb as they were at $32.2^{\circ} \mathrm{C}$ wet bulb (Figs 3 and 5). However, they were still of great benefit to the wearers. They depressed rectal temperature by $1.5^{\circ} \mathrm{C}$ and heart rate by 20 to 30 beats/ $\mathrm{min}$. They allowed the men to maintain equilibrium with their environment for three hours of work. During the fourth hour rectal temperatures and heart rates rose. In ORL's case the rise was certainly enhanced by the almost complete cessation of sweating.

Reactions during 6 hours of work at $33.9^{\circ} \mathrm{C}$ wet bulb The water temperature and flow rate in the watercooled vest were $9.5^{\circ} \mathrm{C}$ and $50 \mathrm{litres} / \mathrm{hr}$, respectively.
The conditions of the test environment were temperatures of $33.9^{\circ} \mathrm{C}$ wet bulb, $35.6^{\circ} \mathrm{C}$ dry bulb, and a wind velocity less than $0.5 \mathrm{~m} / \mathrm{sec}$. When used, the water-cooled vest was worn for the full six hours. The first ice-jacket was donned after one hour of work and replaced by the second jacket after a further two and a half hours of work.

Figure 6 summarizes the results of exposures at $33.9^{\circ} \mathrm{C}$ wet bulb. Values of rectal temperature, heart rate, and sweat rate are shown for six hours of work with protection. For comparison, the values during the four hours of unprotected work and four hours of work in a neutral environment are given.

For both subjects the water-cooled vest performed as well for six hours of work as for the four hours of work. After six hours of work DUS had a rectal temperature of $37.6^{\circ} \mathrm{C}$ and a heart rate of 102 beats/min, while ORL had values of $37.2^{\circ} \mathrm{C}$ and 92 beats/min. These values do not differ much from the four-hour values in a neutral environment. The
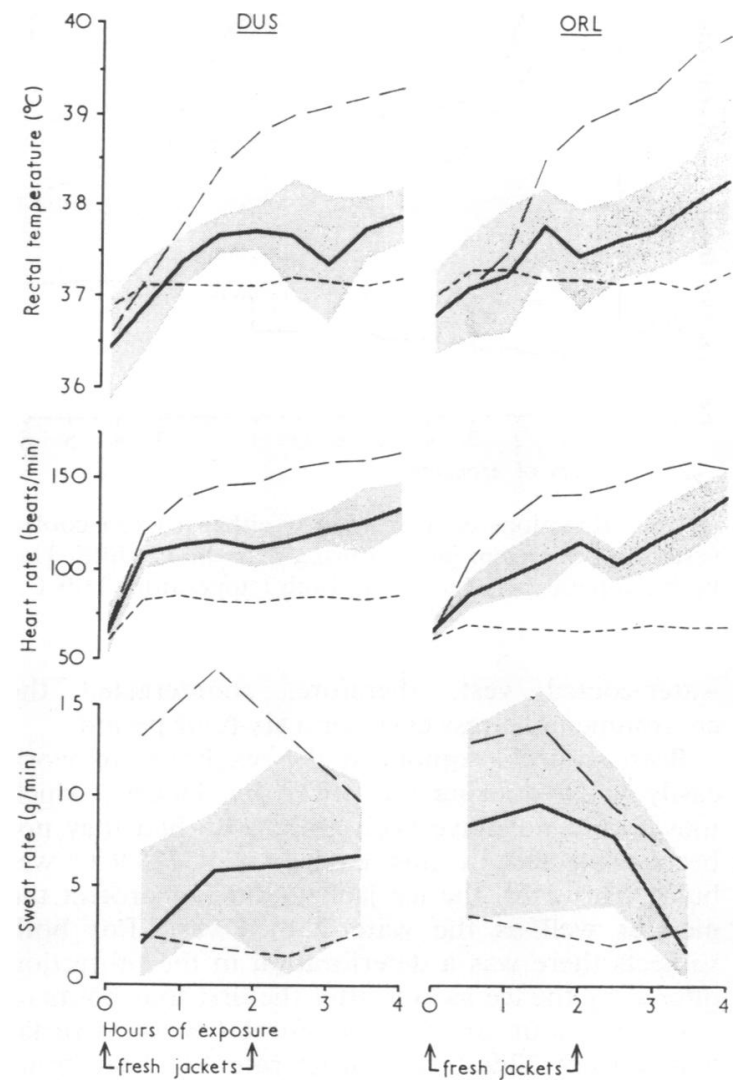

FIG. 5. Reactions of men wearing pre-frozen jackets donned at 0 and 2 hours. Dry bulb temperature $35.6^{\circ} \mathrm{C}$, wet bulb temperature $33 \cdot 9^{\circ} \mathrm{C}$. 

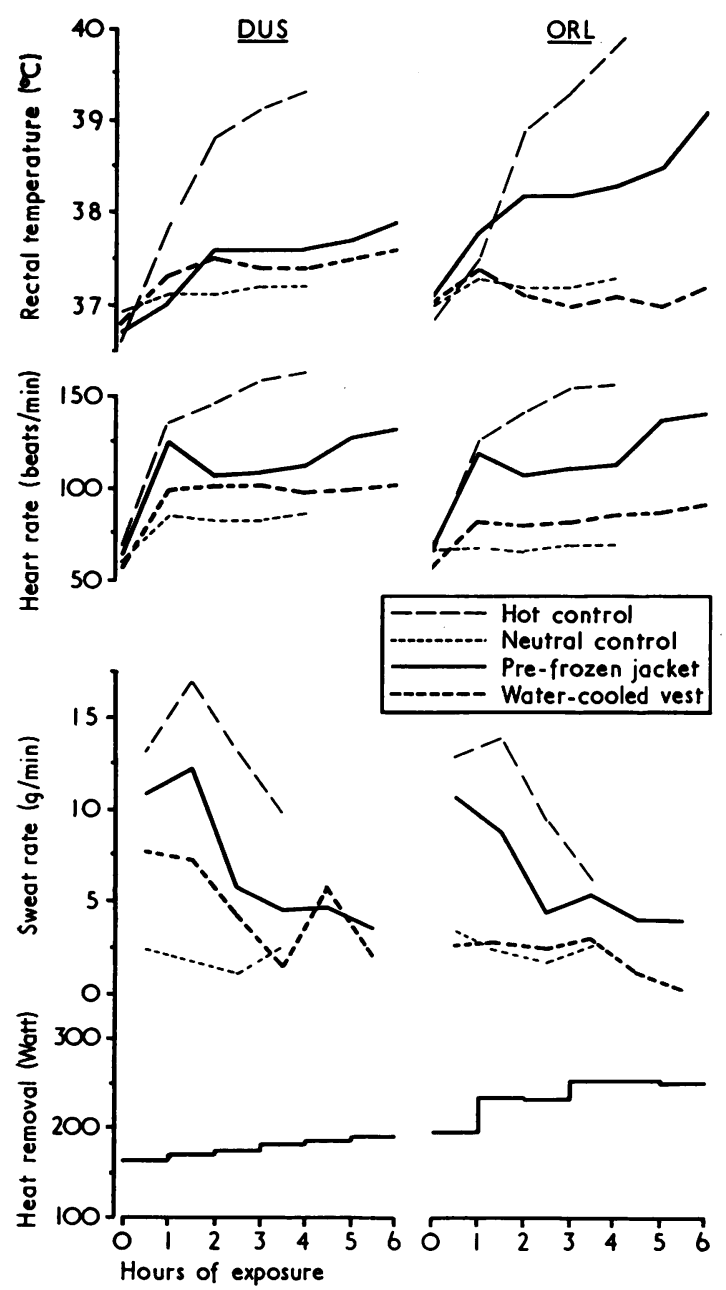

FIG. 6. Reactions of men wearing either a water-cooled vest or a pre-frozen jacket during a six-hour 'shift'. Dry bulb temperature $35.6^{\circ} \mathrm{C}$, wet bulb temperature $33.9^{\circ} \mathrm{C}$.

water-cooled vest, therefore, counteracted the environmental stress even for a six-hour period.

Both subjects completed the six hours of work easily when wearing the pre-frozen jackets, which they would not have been able to do had they not been protected in this environment $\left(33.9^{\circ} \mathrm{C}\right.$ wet bulb). However, the ice jackets did not protect the men as well as the water-cooled vest. For both subjects there was a deterioration in the protection offered by the ice jackets after the first four hours of work. Six-hour strain values for DUS were: rectal temperature $37.9^{\circ} \mathrm{C}$ and heart rate 133 beats/min; for ORL: rectal temperature $39 \cdot 1^{\circ} \mathrm{C}$ and heart rate 141 beats/min. It is also clear that ORL being theat intolerant', was much worse off than subject DUS.

\section{Discussion}

The first hour

It is evident from Figs 2 and 3 that wearing either the water-cooled vest or the pre-frozen jackets had very little effect on the heart rate or rectal temperature during the first hour of work. The sweat rate during the first hour was depressed but not significantly so. This unexpected result was confirmed by all the exposures at $32.2^{\circ} \mathrm{C}$ wet bulb but was absent at higher temperatures (Figs 4 and 5).

The ineffectiveness of the microclimate conditioners during the first hour of exposure to $32.2^{\circ} \mathrm{C}$ wet bulb temperature raises the question whether there is any point in wearing such protective clothing during this initial period.

\section{Six hours}

From a practical point of view it is important to know whether or not microclimate conditioners can protect men during six hours of work, this being more typical of a 'shift' than four hours. Using two ice jackets over six hours resulted in a slight increase of the physiological strain shown by the subjects compared with the use of one jacket over four hours. This could probably be counteracted by using three ice jackets or by a better design. Men wearing the water-cooled vest for six hours in an environment of $33.9^{\circ} \mathrm{C}$ wet bulb and $35.6^{\circ} \mathrm{C}$ dry bulb showed no physiological signs of having been exposed to heat.

Water-cooled vest versus pre-frozen jacket

Pre-frozen jackets have the distinct advantage of being self-contained and very cheap. The benefits they can provide have been demonstrated in hot humid environments. The quality of the protection they afforded did not match that afforded by the water-cooled vest. However, the effectiveness of the pre-frozen jackets could probably be improved considerably by improving the design.

The water-cooled vest has a higher cost (perhaps even an order of magnitude higher) and needs a trailing hose. The trailing hose presents an obvious disadvantage because it limits the mobility of the wearer. However, the water requirements are low ( 50 litres/hr) and a single plastic supply hose of $5 \mathrm{~mm}$ diameter would be sufficient. It is much cheaper to supply water at 10 to $15^{\circ} \mathrm{C}$ than to freeze water. The wearer of a water-cooled vest could take advantage of the long thermal time constants of his body and disconnect from his cooling water supply for periods of 20 to 30 minutes provided he reconnected for equivalent periods afterwards. Quick-fitting, selfsealing connectors are available. The water-cooled vest is less than one-tenth of the weight of a prefrozen jacket.

\section{Psychological effects}

The psychological effects were more dramatic and perhaps more important than the physiological 
effects. The subjects, when wearing microclimate conditioners, showed high spirits, laughing and joking with the scientists, even at the end of six hours of work in environments with wet bulb temperatures of $33.9^{\circ} \mathrm{C}$. The symptoms of psychological distress often shown by men exposed to high heat stress (Wyndham, 1969) were entirely absent when the men wore microclimate conditioners. If microclimate conditioning improves the physiological and psychological well-being of men working under stress, it achieves its purpose. There is every indication that it will improve productivity as well.

A number of aspects of the physiology of microclimate cooling still need investigation, for instance, the increase in oxygen demand of a task due to the wearing of additional garments; the effect of wearing additional garments on productivity; the maximum environmental stress that can be counteracted; the maximum environmental stress level at which it is necessary to condition inspired air; the effect on the thermoregulatory system when the input consists of a combination of very hot and very cold signals.

\section{Conclusion}

This study has shown quite conclusively that microclimate conditioning can be used in hot humid environments to combat environmental heat stress, even at very high levels of stress. The effectiveness of the cooling suits has been proved by showing that the suits reduce physiological strain (rectal temperature, heart rate, and sweat rate) and psychological distress substantially. Very often the suits offer protection physiologically equivalent to counteracting the environmental heat stress completely.

This paper is published with the permission of the Chamber of Mines of South Africa.

We are grateful for the stimulating discussion and criticism of Professor C. H. Wyndham.

The Figures were prepared by Mr. D. Rabe.

\section{References}

Blockey, W. V. (1970). A passive cooling system for microclimate control in hot industry. Ergonomics, 13, 527-528.

Burton, D. R. (1964). The development of water conditioned suits. Technical Notes No. Mech. Eng. 400. Royal Aircraft Establishment, Ministry of Aviation, London, England.

Dunn, O. J. (1961). Multiple comparisons among means. J. Amer. statist. Ass., 56, 52-64.

Nunneley, S. A. (1970). Water cooled garments: a review. Space Life Sciences, 2, 335-360.

Wyndham, C. H. (1969). Adaptation to heat and cold. Environ. Res., 2, 442-469.

_ - Strydom, N. B., Morrison, J. F., Williams, C. G., Bredell, G. A. G., von Rahden, M. J. E., Holdsworth, L. D., van Graan, C. H., van Rensburg, A. J., and Munro, A. (1964). Heat reactions of Caucasians and Bantu in South Africa. J. appl. Physiol., 19, 598-606.

Received for publication November 9, 1971. 